\title{
Conversion of a Solar Geyser to Solar Cooker \& Its Performance Evaluation
}

\author{
Muhammad Babar Iqbal ${ }^{1}$, Suhail Zaki Farooqui ${ }^{2}$, Muhammad Arsalan Wahid ${ }^{3}$ \\ ${ }^{1,2,3}$ Department of Renewable Energy Engineering, U.S.-Pakistan Center for Advanced Studies in Energy, University \\ of Engineering and Technology Peshawar, Pakistan \\ engr.mbabariqbal@gmail.com ${ }^{1}$,drsuzaki@ hotmail.com²,engr.arsalan6@gmail.com \\ Received: 03 February, Revised: 11 February, Accepted: 13 February
}

\begin{abstract}
For reducing the consequences of global warming and fuel scarcity, we need to change dilemma in terms of cooking. For resolving this issue, the solar cooking offers the best alternative. There are various designs of solar cookers. Different types of solar cookers are presented by a number of researchers over the decade that includes the box type solar cookers and parabolic type solar cookers. However, these types of solar cookers have limited performance in terms of tracking and operating during night time. An evacuated tube solar geyser is converted into a solar cooker which is obsolete from tracking and cooking can also carried out during night time having a thermal storage unit (TSU). The performance of the system is observed during clear days and nights of August and September 2019 in Peshawar, Pakistan. The maximum temperature attained by the system is recorded $98.5{ }^{\circ} \mathrm{C}$. From the observed experimented data, the results indicate that the system is faithfully performing under the required climate conditions.
\end{abstract}

Keywords - TSU Thermal storage unit, Evacuated tube solar geyser

\section{INTRODUCTION}

Cooking is one of the major necessities for people around the world. That accounts for one-third of the energy of the total primary energy consumptions in the developed countries of the world [1]. There are about 2.9 billion people still dependent on biomass fuels for cooking [2]. These fuels include firewood, charcoal, dung, and agricultural residues which contribute to greenhouse gases. In rural areas, biomass fuels are the only available energy source for cooking. It's been estimated that more than 2.52 billion people will still dependent on biomass fuels by the end of 2030 [2]. It is therefore highly desirable to establish complementary, appropriate and inexpensive cooking methods based on renewable sources of energy. Therefore, the solar energy is one of the efficient, environmental friendly and affordable alternative solution for cooking. In Asian countries the solar energy has very high potential. Horace de Saussure presented the first ever solar oven in $18^{\text {th }}$ century after that many types of solar cookers have been emerged $[3,4]$. Various designs of solar cookers are in used in many parts of the world to fulfill the domestic needs of the users. The most common type solar cookers available are the direct type box type solar cookers and the parabolic type solar cookers [5]. The direct type solar cookers have limited performance in terms of frequently tracking the sun and lack of TSU (Thermal storage unit) for preparing the food during the night time. In order to resolving the need of thermal storage unit, the solar cookers having vacuum tube collectors are the best option. Solar cookers having evacuated tube collectors have several advantages: they do not need constant supervision to track the solar rays, they can attain very high temperatures and the cooking can also be performed in the shade or inside a building (kitchen.) in order by placing the storage unit (TSU) inside the building. For considering such design that consist of having the evacuated tube collectors and the Thermal storage unit (TSU), the solar geyser is the best option. In order to fabricate such design that can perform cooking during day and night time and also the stored water can also be used for cleaning purposes. Solar geyser cooker is one of the most effective way to harness the solar energy for cooking, drinking and cleaning purposes.

This paper presents the designing of a solar geyser cooker for cooking of water base ingredients e.g beans, rice, meat, vegetables etc. Further more performance of the system has also been analyzed, such as temperature inside the cooker, ambient temperature, solar irradiance to evaluate the performance of the solar cooker. Performaning such analysis the system has been installed at roof top at the Energy Center of UET, Peshawar.

\section{MATERIALS AND METHODS}

\section{A. Description of the Solar Geyser Cooker}

The Solar geyser has been modified and fabricated as shown in fig 8. It is composed of 3 major parts the supporting stracture, the collector and the thermal storage unit. The length of the external storage unit is $94.80 \mathrm{~cm}$ while its height is $45.7 \mathrm{~cm}$, the length of the internal tank is $64 \mathrm{~cm}$ while its height is $35.5 \mathrm{~cm}$, between the two tanks a two inch thickness of insulator is provided for keeping the water hot for a very longer period. A head of the storage tank has been designed for placing the cooking pots inside the storage tank. The head of the storage tank is basically divided into three parts, the upper section, the 
lower section and in the middle a 2 inch thinck polyurethane insulator. The outer section length of the head is $25 \mathrm{~cm}$ and width $25 \mathrm{~cm}$ while the inner section of the head is $18 \mathrm{~cm}$ in legth and $18 \mathrm{~cm}$ in width. The capacity of the storage tank is 100 liters. The water will be used as a sensible heating medium for cooking. The collectors of the system are evacuated tube collectos. There are total 10 number of tubes that are connected to the storage unit in order to capture the solar energy for heating the water. Each tube is $173 \mathrm{~cm}$ long with a diamerter of $4.2 \mathrm{~cm}$. The speciality of evacuated tube collectors, they do not need tracking mechanism. They can attain very high temperatures upto $300{ }^{\circ} \mathrm{C}$. Due to the precence of vaccum inside these tubes, the heat loss is nearly negligible.

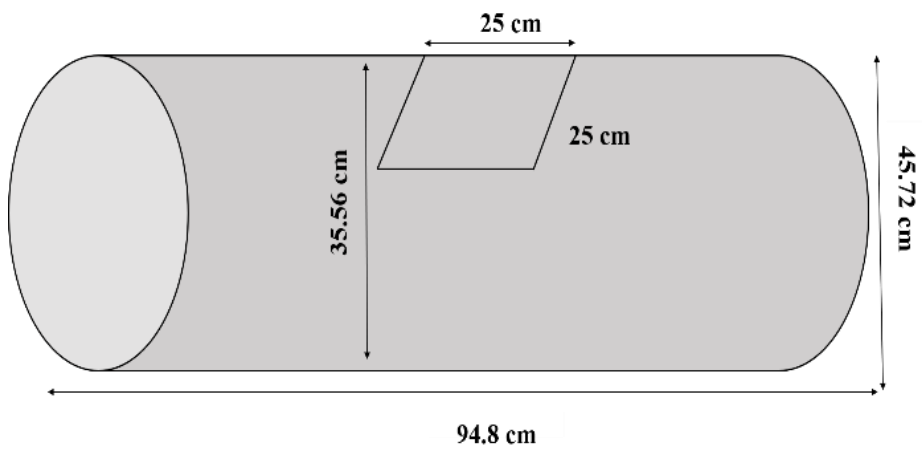

Figure 1. Model of TSU of the solar cooker

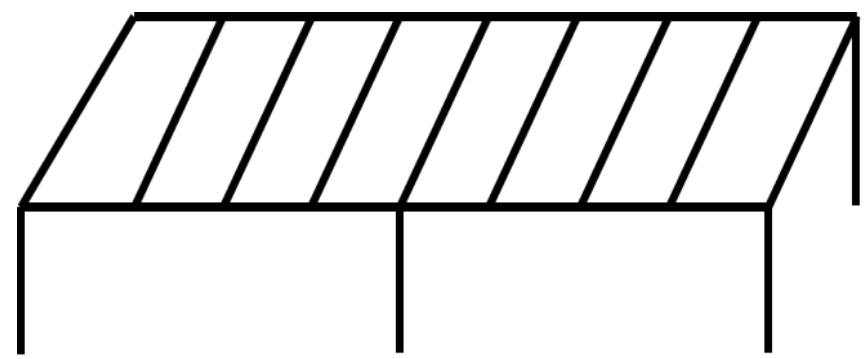

Figure 2. Supporting stand for holding cooking pots inside TSU

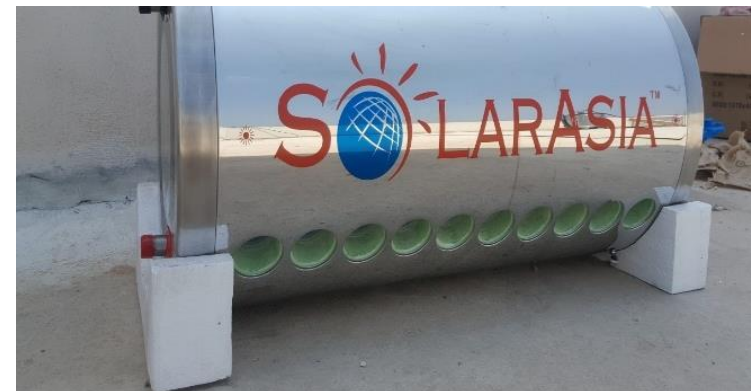

Figure 3. Tank of solar geyser

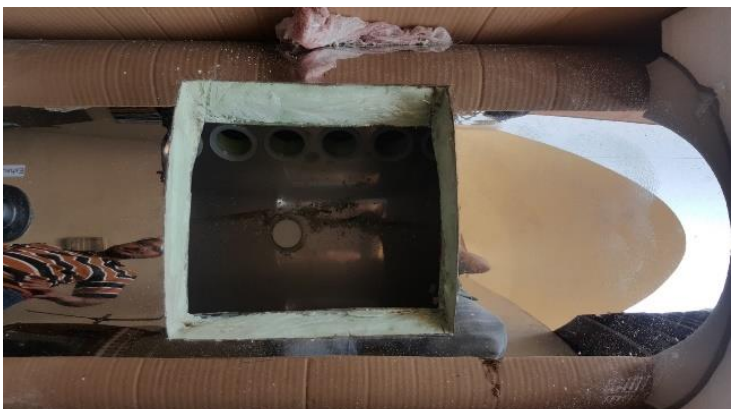

Figure $4.25 \mathrm{~cm} \mathrm{X} 25 \mathrm{~cm}$ cell has been made at the top of the tank

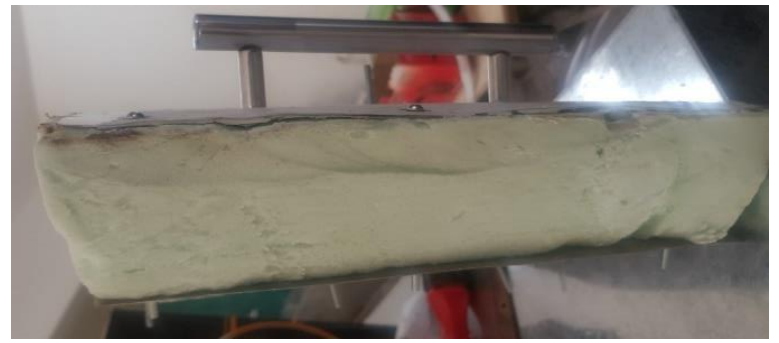

Figure 5. Lid of the TSU with insulation in between

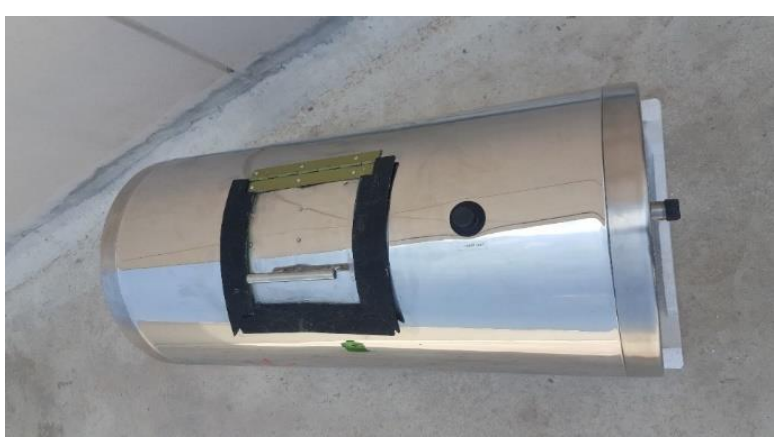

Figure 6. TSU with closed lid 


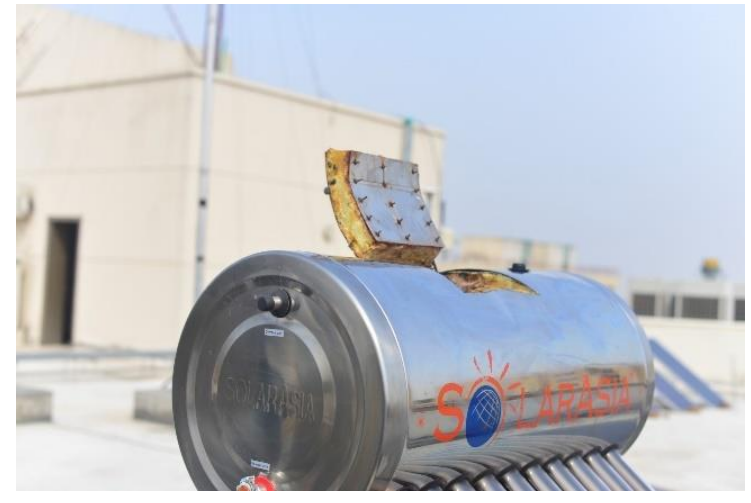

Figure 7. TSU with open lid

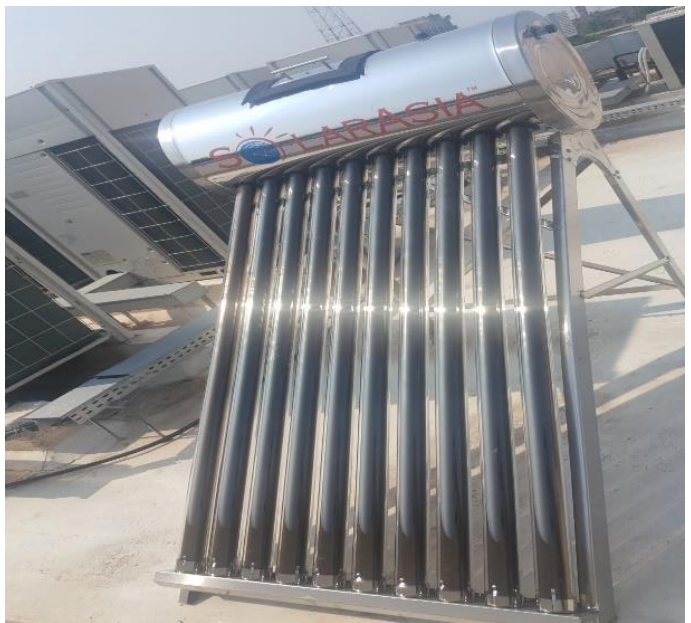

Figure 8 . The complete solar geyser solar cooker system

\section{B. Performance Evaluation of the Solar Cooker}

Experiments were conducted on a prototype mode of solar geyser cooker during the month of August and September 2019 in Hayatabad, Peshawar with a tilt angle of the collector $34^{\circ}$. The following quantities were measured during testing of the performance evaluation of the system: Solar irradiance ( $\left.\mathbf{I}_{\mathbf{0}}\right)$, Ambient temperature $\left(\mathbf{T}_{\mathbf{A}}\right)$, Thermal storage unit temperature $\left(\mathbf{T}_{\mathbf{s}}\right)$ and time $(\mathbf{T})$. The data was registered by using a data logger and a pyranometer in intervals of $10 \mathrm{~min}$. The temperatures were measured using $\mathbf{N i C r}-\mathbf{N i}$ thermocouples. One was attached inside the TSU $\left(\mathbf{T}_{1}\right)$ and the other one was attached outside of the TSU in order to measure the ambient temperature of the solar cooker surrounding $\left(\mathbf{T}_{2}\right)$. The inner tank of the Solar geyser is stainless steel which have a capacity of 100 liters. Water has been filled inside the inner tank of the solar geyser up to 72 liters. While the outer tank of the solar geyser is made from a Galvanized steel. Between inner tank and outer most tank of the solar geyser insulation has been provided with a material called polyurethane which is quite feasible effective and cheap. Performing the performance evaluation task, the head of the storage tank of the solar geyser cooker system has been carefully closed in order to avoid any losses during the recording of readings. Three different days of the months and nights reading have been recorded. The procedure of collecting data during day time is a bit different from data collection during night time.

\section{1) $T_{A} \& T_{S}$}

A digital data logger (TM-947SD) was used for measuring the ambient temperature (TA) and the the temperature of the storage unit (TS). The data logger was set with a duration of 0 600 seconds. After every $10 \mathrm{~min}$ the data logger automatically record the required temperatures.

\section{2) Solar Radiation Intensity}

A meteorological grid was used for taking the solar radiation intensity readings.

3) Efficiency of the cooker

The efficiency of the solar cooker was calculated by using the following equation

$$
\eta_{s c}=\frac{E_{O U T}}{E_{I N}}
$$

$\boldsymbol{\eta}_{\text {sc }} \quad$; Efficiency of Solar Cooker

Eout ; Output Energy

EIN ; Input Energy

a) Input Energy $\left(\boldsymbol{E}_{I N}\right)$

Ac ; Collector Area

$$
E_{I N}=A C * I * 600
$$

I ; Solar Irradiance

600 ; number of seconds of each interval

b) Output Energy (EоuT)

$$
\boldsymbol{E}_{\text {OUT }}=\Delta \boldsymbol{T} * \boldsymbol{M} * \boldsymbol{c}_{\boldsymbol{p}}
$$

$\Delta \mathbf{T}$; Temperature difference during 600 seconds ineterval

M ; Mass of fluid inside the storage tank

$\mathbf{c}_{\mathbf{p}}$; Heat capacity of the fluid (for water $4186 \mathrm{~J} / \mathrm{kg}{ }^{\circ} \mathrm{C}$ )

\section{RESULTS AND DISCUSSIONS}

There are total 11 experiments were conducted on this prototype model of solar geyser cooker. Three experiments were conducted on three different days for the collection of data during data daytime and three experiments were conducted on three different night for the collection of data during night time. Furthermore 5 different dishes were also cooked in order to evaluate the performance of the system.

\section{A. Data Collection During Day Time}

In this section, three experiments were conducted on different days of the month to observe the performance evaluation of the solar geyser cooker. For conducting day time readings and observing the maximum temperature with respect to solar irradiance and time. Fresh water has been filled early in the morning just before the sun rise in order to observe the collector performance in how much time the system can attain the maximum temperature. All the measurement instruments are connected for recording the real time readings. After filling water in the storage tank with a capacity of 72 litters by observing it very carefully and connecting all the devices the meters are now ready to start. All of these experiments are performed at the energy center of uet Peshawar. After conduction the readings and putting all the data in the excel sheet following graphs are obtained, 


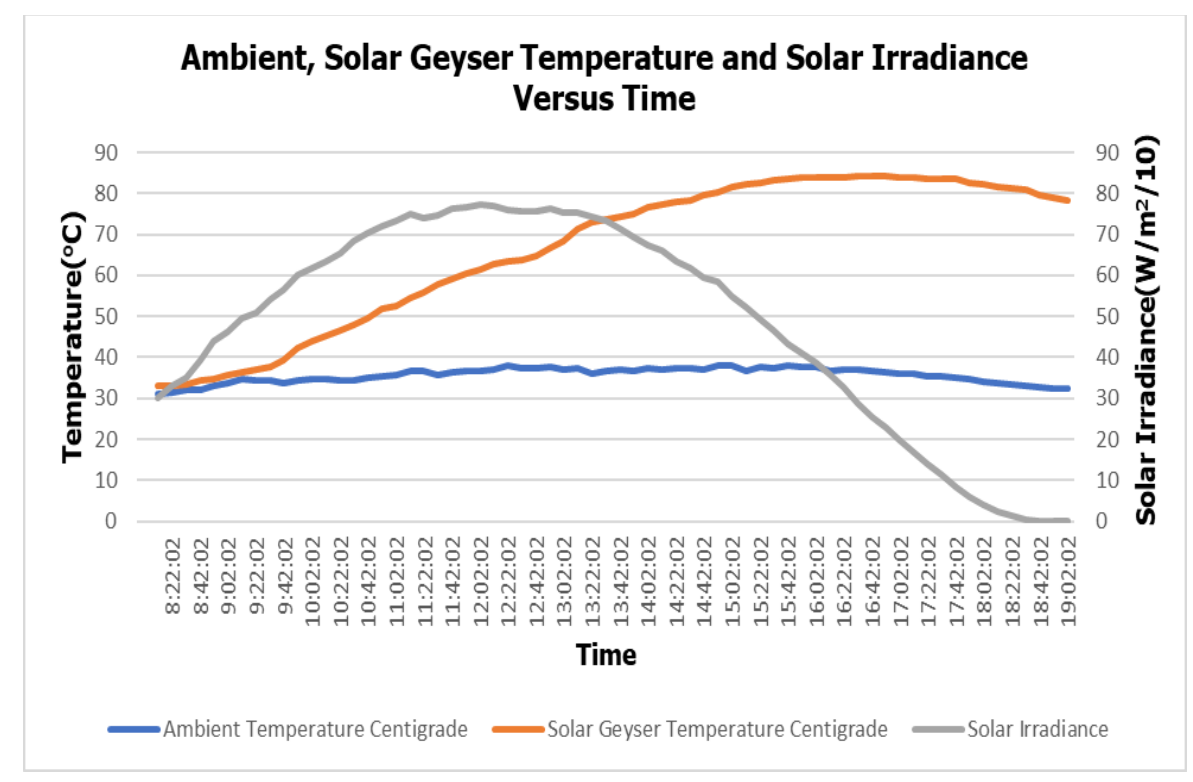

Figure 9 Variation of solar irradiance, ambient air temperature \& thermal storage unit of solar geyser temperature on one-day test run with water on 8 September 2019.

The first measurement was conducted on $8^{\text {th }}$ September 2019 at day time as show in the Fig 9. Four quantities have been shown on the plot, the blue line indicates the Ambient temperature of the Solar cooker surrounding $\left(\mathrm{T}_{\mathrm{A}}\right)$, the orange line indicates the temperature inside the thermal storage unit of the solar cooker $\left(\mathrm{T}_{\mathrm{S}}\right)$ while the silver line shows the Solar irradiance $\left(\mathrm{I}_{\mathrm{o}}\right)$. From the graph it can observe at 8:22 am in the morning the ambient temperature was $31{ }^{\circ} \mathrm{C}$ while the solar irradiance was recorded 300 watt per square meter and the temperature inside the cooker has been recorded $33{ }^{\circ} \mathrm{C}$ due to some water that was already stored inside the tubes. In just 6 hours and 30 minutes, the solar cooker attains its peak temperature of $84^{\circ} \mathrm{C}$ of that day. From the graph it can be observed as the time passes the solar irradiance also decreasing, At $7 \mathrm{pm}$ of the evening the solar irradiance comes to zero while the temperature inside the storage unit is still at its peak and is quite stable. There is no fluction has been observed after the sunset inside the storage unit temperature. Which shows that the system can also be used for cooking during night time.

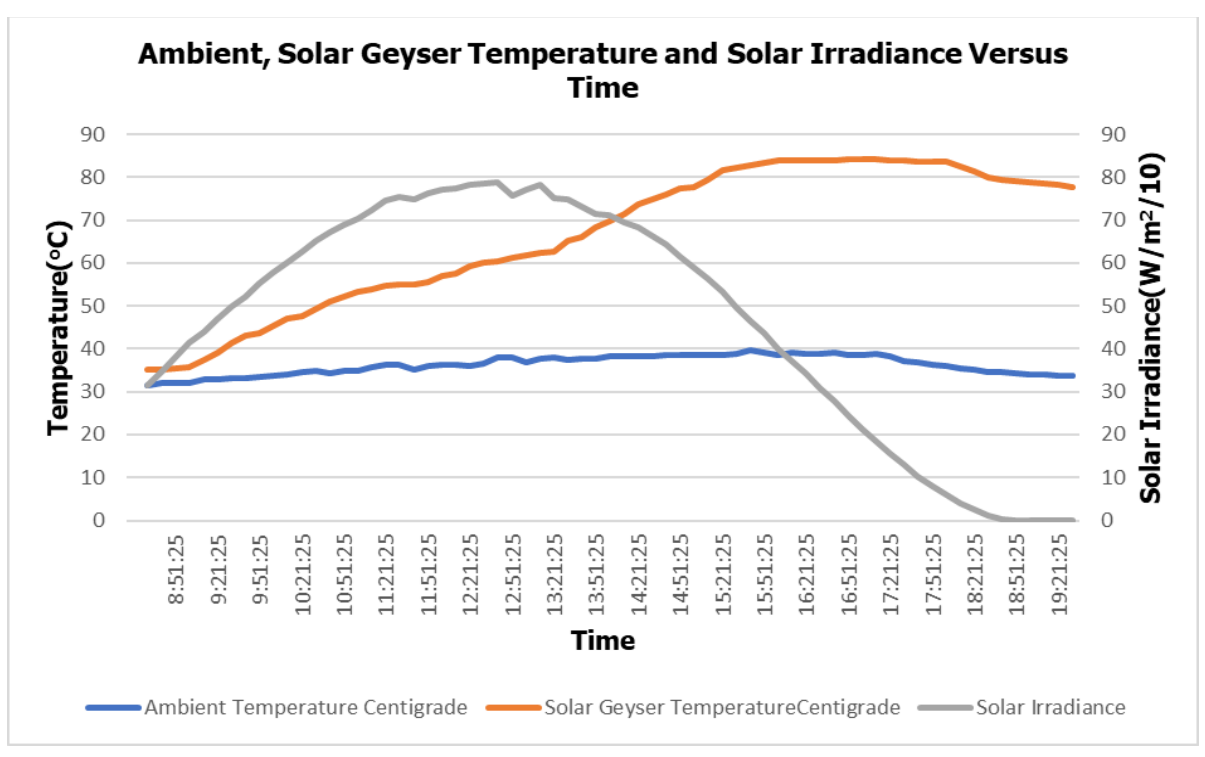

Figure 10. Variation of solar irradiance, ambient air temperature \& thermal storage unit of solar geyser temperature on one-day test run with water on 9 September 2019. 
The Second measurement has been performed on 9th September 2019 shown in fig 10. Same procedure has been applied as the previous experiment. The 1 st reading was conducted at 8:21 am in the morning. In 6 hours and 20 minutes the system attained its maximum temperature of $84.1 \mathrm{oC}$ which is quite similar to the previous the reading.

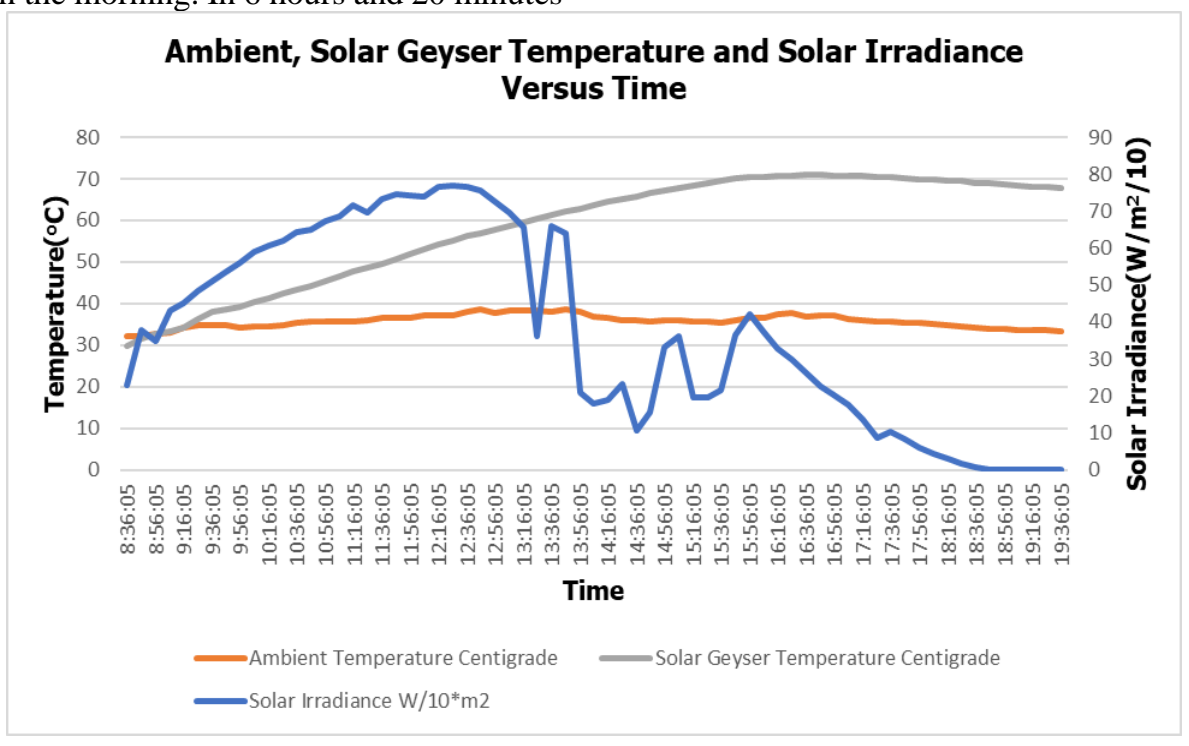

Figure 11. Variation of solar irradiance, ambient air temperature \& thermal storage unit of solar geyser temperature on one-day test run with water on 24 September 2019

The 3rd and final reading of the day time was conducted on 24th September 2019 which was quite hazy day as we can observe it from the plot fig 11 . From the figure the blue line indicate the solar irradiance while the orange and silver line indicate the ambient temperature and the solar geyser cooker temperature. Having a cloudy day still the performance of the system is not affected and the cooking can also be carried out. The maximum temperature attained by the system in 6 hours and 50 minutes which was recorded $80 \mathrm{oC}$.

\section{B. Data Collection During Night Time}

In order to evaluate the performance of the system during night time 3 experiments have been performed for the collection of data during night time. From that data we can conluded that whether the system is stable for cooking during night time or not stable. Regarding collection of data during night time, three parameters have been observed the $T_{A}$ and the $T_{S}$ with respect to time. After the collection of data following graphs are obtained,

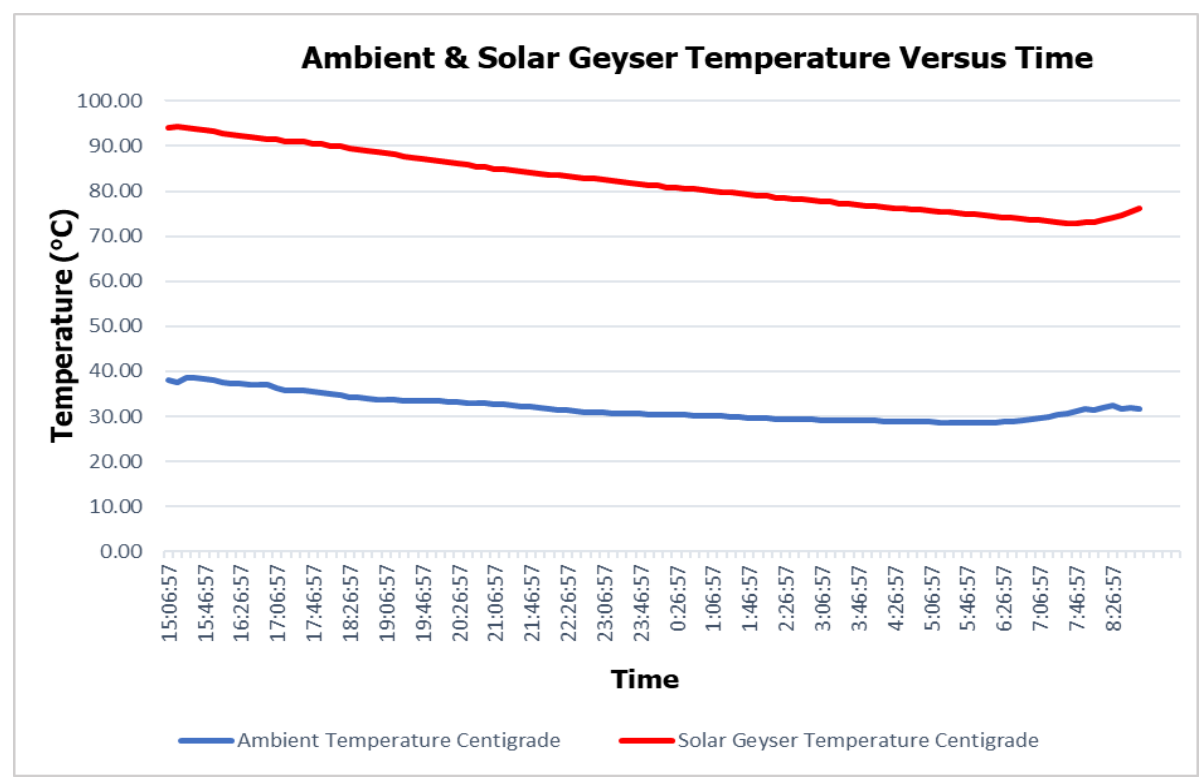

Figure 12. Variation of ambient air temperature \& thermal storage unit of solar geyser temperature on one-day test run with water on night of September 10, 2019. 


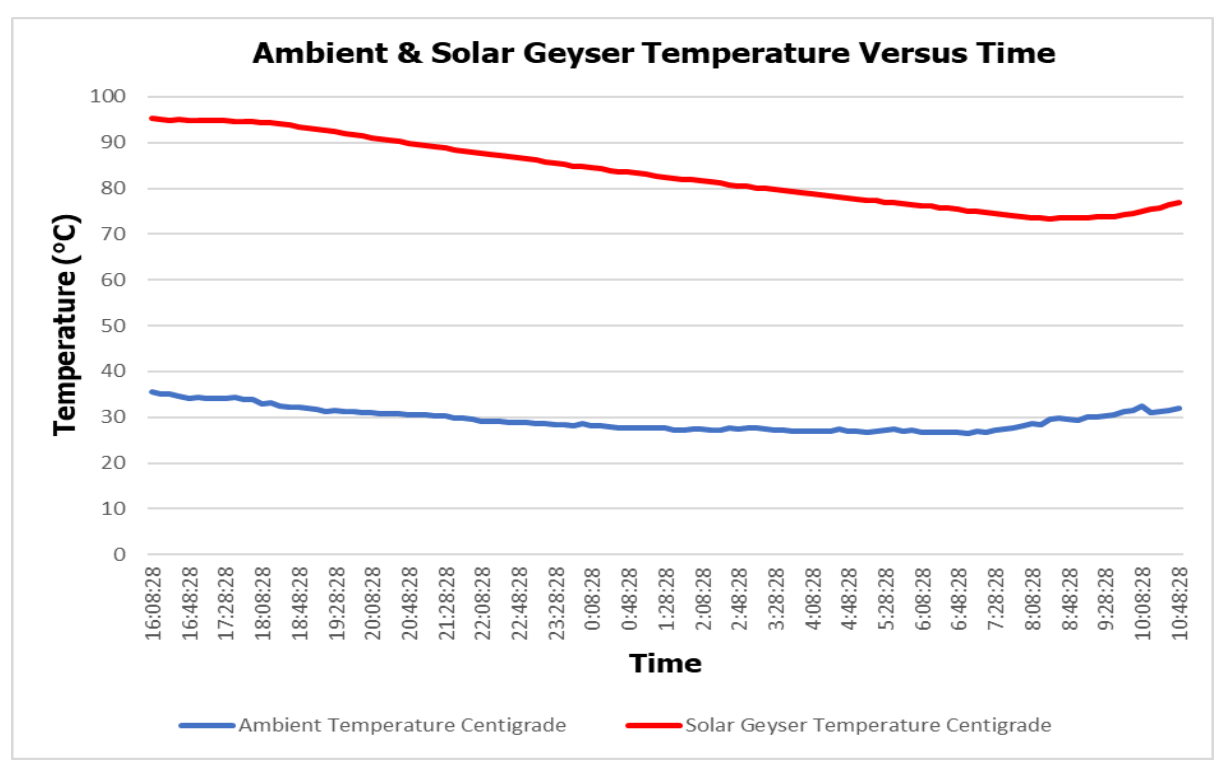

Figure 13. Variation of ambient air temperature \& thermal storage unit of solar geyser temperature on one-day test run with water on night of September 15, 2019

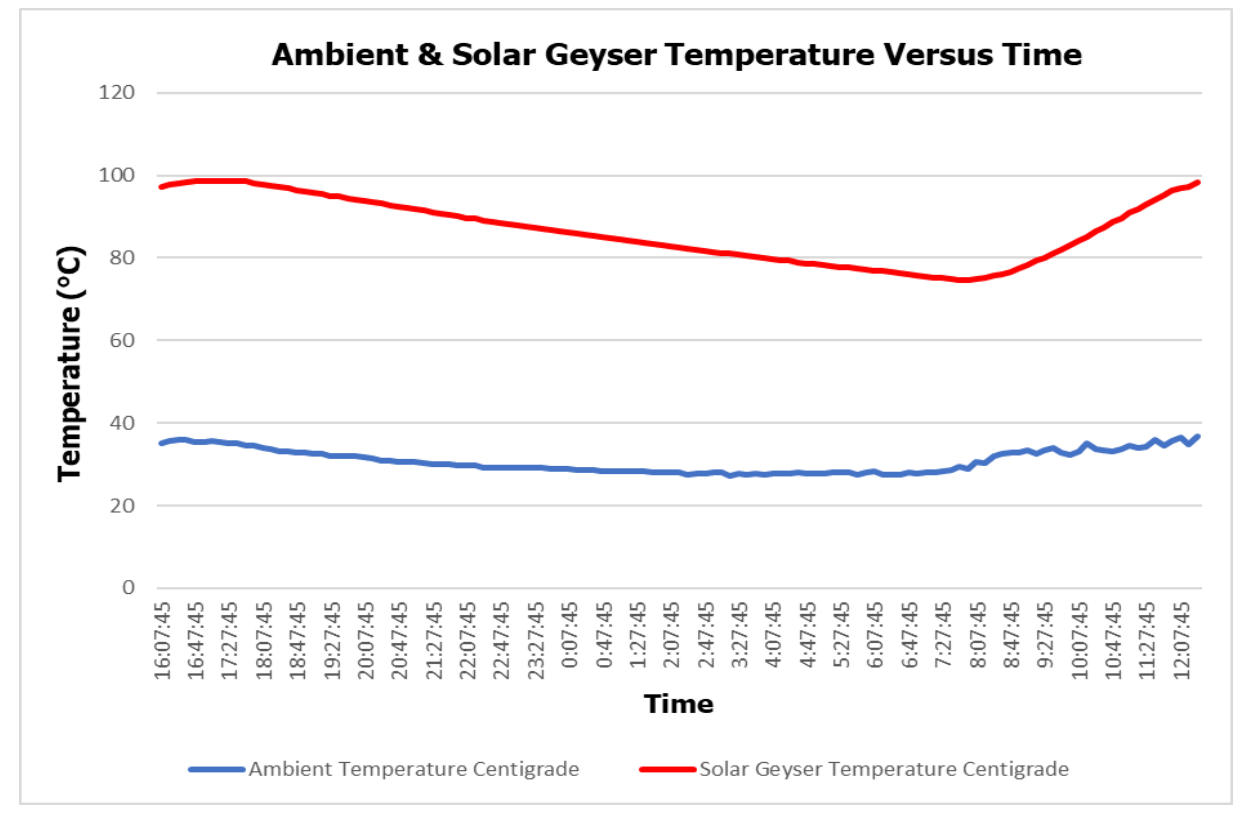

Figure 14. Variation of ambient air temperature \& thermal storage unit of solar geyser temperature on one-day test run with water on night of September 17, 2019

TABLE I. PERFORMANCE DURING NIGHT TIME

\begin{tabular}{|c|c|c|c|}
\hline \multirow{2}{*}{$\begin{array}{c}\text { S. } \\
\text { no }\end{array}$} & \multicolumn{4}{|c|}{ Average Temperature Each Night } \\
\cline { 2 - 4 } & Day/Month/Year & $\begin{array}{c}\text { Starting Time of } \\
\text { Reading }\end{array}$ & $\begin{array}{c}\text { Average } \\
\text { Temperature }\end{array}$ \\
\hline 1 & September 10, 2019 & $7: 00 \mathrm{pm}$ to $9: 00 \mathrm{am}$ & $82^{\circ} \mathrm{C}$ \\
\hline 2 & September 15, 2019 & $7: 00 \mathrm{pm}$ to $10: 00 \mathrm{am}$ & $83.3^{\circ} \mathrm{C}$ \\
\hline 3 & September 17, 2019 & $7: 00 \mathrm{pm}$ to $9: 30 \mathrm{am}$ & $86.5^{\circ} \mathrm{C}$ \\
\hline
\end{tabular}




\section{Efficiency of the System}

From the recorded data during day time, the efficiency of the system of each day are plotted,

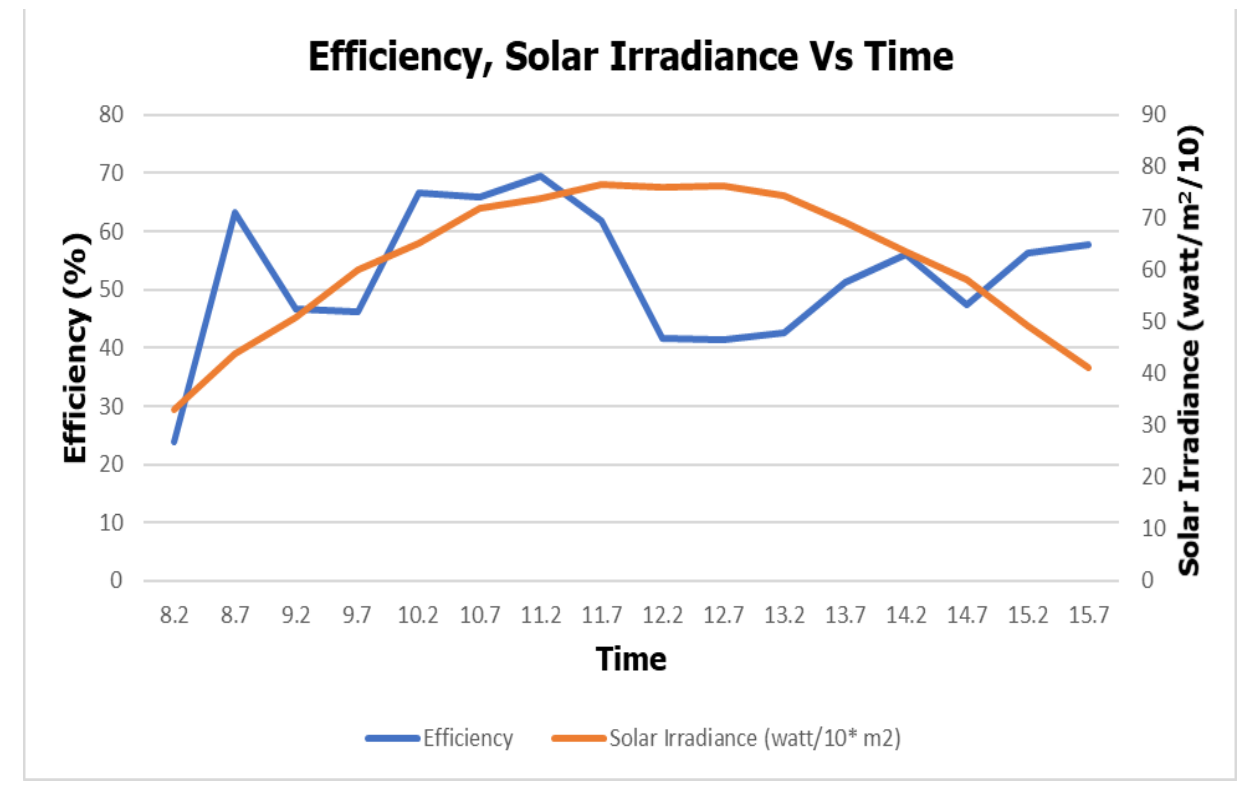

Figure 15. Variation of efficiency \& solar Irradiance with respect to time of thermal storage unit on one-day test run with water on September 8, 2019

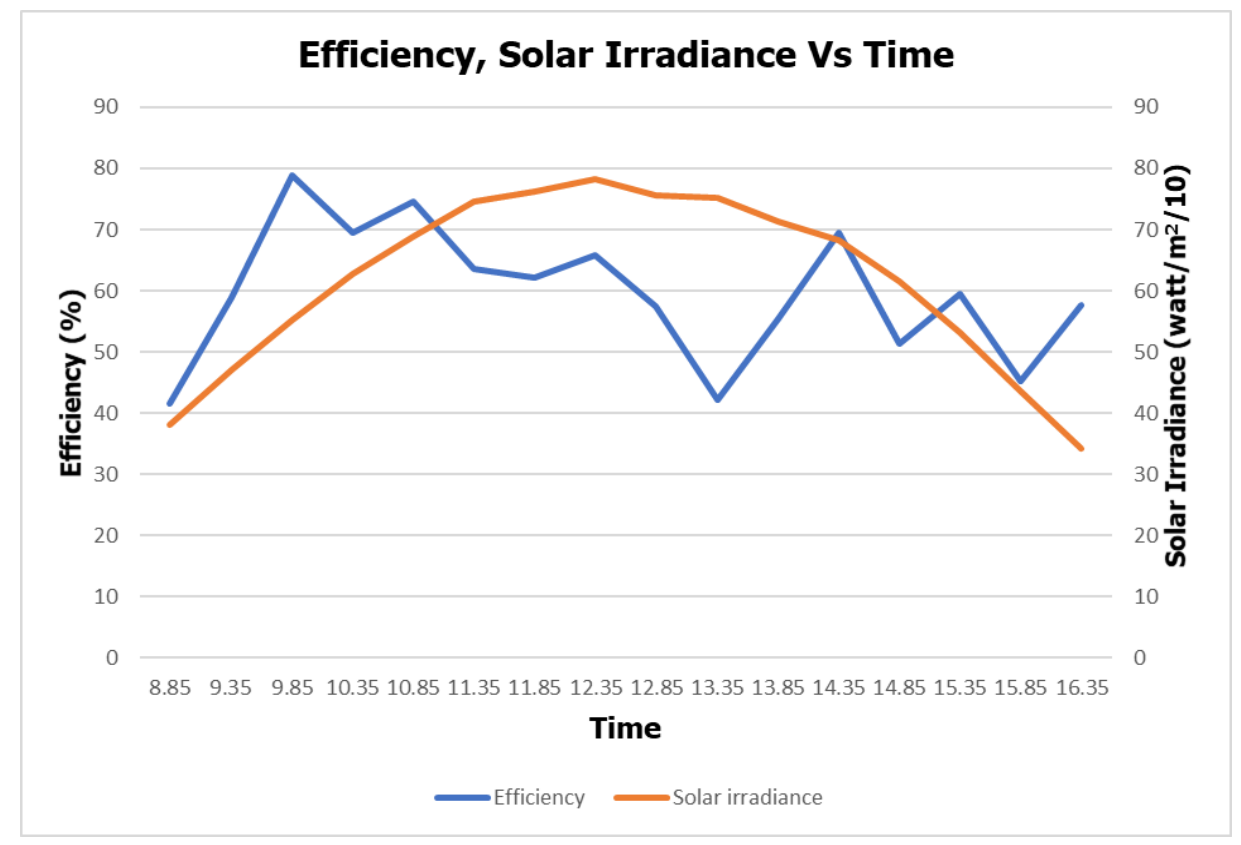

Figure 16. Variation of efficiency \& solar Irradiance with respect to time of thermal storage unit on one-day test run with water on September 9, 2019. 


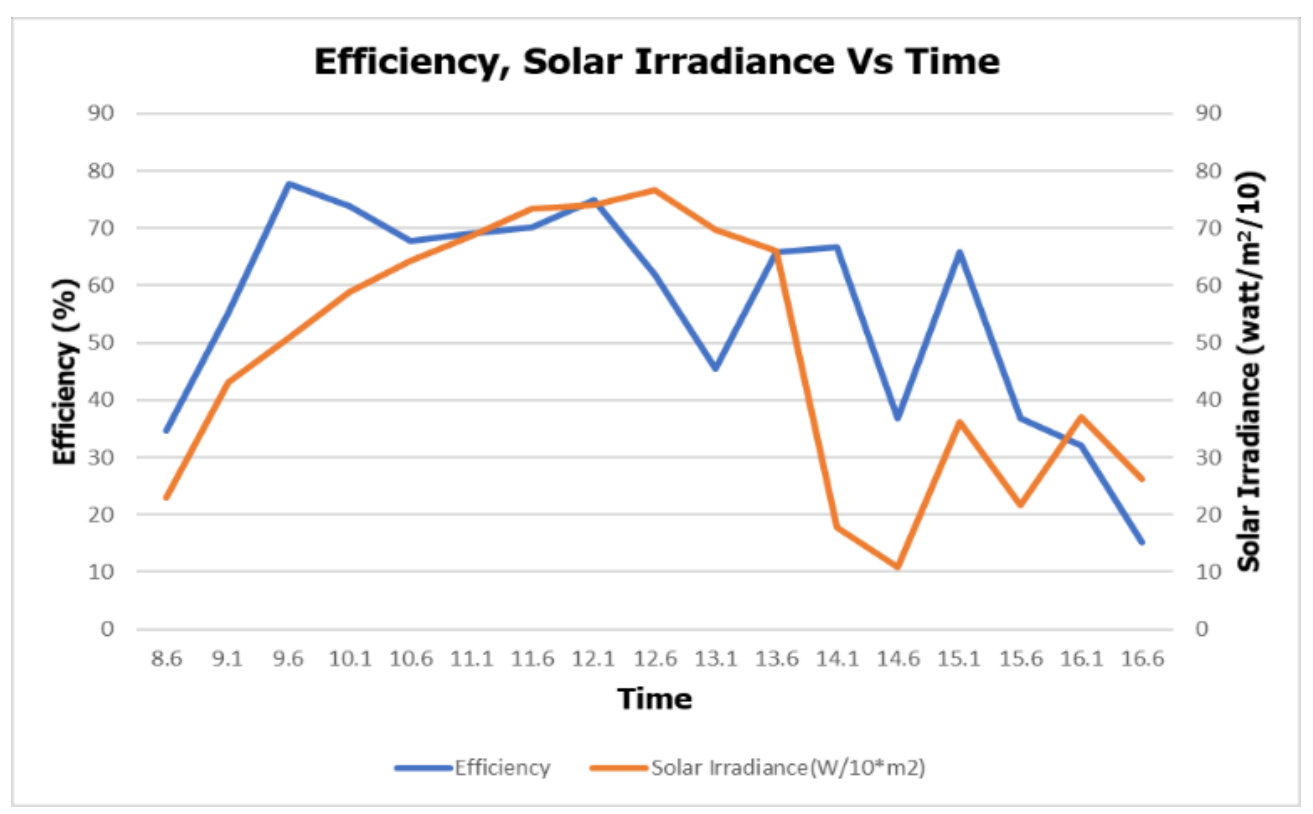

Figure 17. Variation of efficiency \& solar Irradiance with respect to time of thermal storage unit on one-day test run with water on September $24,2019$.

The preceding experimentally calculated plots indicate the $\eta_{\mathbf{e}}$ of the solar geyser turned solar cooker. As sunrays fall on the tubes the solar geyser starts functioning and the temperature rises. From the results, it is indicated that the rise in temperature greatly depends on the capacity of water inside the geyser. In this project, the capacity of the tank was 100 liters and we provided 72 liters of water to the solar geyser to prevent the complete dipping of the cooking pot. The minimum efficiency recorded during the starting time was recorded $11 \%$, while the maximum efficiency was $77.8 \%$. The average efficiency in each case is given in table 2 .

TABLE II. EFFICIENCY OF THE SYSTEM

\begin{tabular}{|l|c|c|}
\hline \multirow{2}{*}{$\begin{array}{c}\text { S. } \\
\text { no }\end{array}$} & \multicolumn{2}{|c|}{ Average Efficiency } \\
\cline { 2 - 3 } & Day/Month/Year & Average Efficiency \\
\hline 1 & September 8, 2019 & $52 \%$ \\
\hline 2 & September 9, 2019 & $57 \%$ \\
\hline 3 & September 24, 2019 & $56 \%$ \\
\hline
\end{tabular}

\section{Experimented Cooked Food by Solar Cooker}

There are total five dishes has been prepared using this prototype. At first experiment three dishes has been prepared during day time which are red beans, white beans and black beans. In second and third experiment which are performed during night, the foods that has been cooked on the solar cooker during night time are the goat feets, and the nihari. The timings of each dish are mentioned in the table which is given below.

TABLE III. COOKED FOOD

\begin{tabular}{|c|c|c|c|}
\hline \multirow{2}{*}{ ITEMS } & \multicolumn{3}{|c|}{ Cooked Food } \\
\hline & Time Required & Date & Time \\
\hline Red Beans & 3 hours & $\begin{array}{c}\text { Sep, } 11 \\
2019 \\
\end{array}$ & $\begin{array}{c}11: 00 \text { to } \\
14: 01\end{array}$ \\
\hline
\end{tabular}

\begin{tabular}{|c|c|c|c|}
\hline \multirow{2}{*}{ ITEMS } & \multicolumn{3}{|c|}{ Cooked Food } \\
\hline & Time Required & Date & Time \\
\hline $\begin{array}{l}\text { White } \\
\text { Beans }\end{array}$ & 3 hours & $\begin{array}{c}\text { Sep, } 11 \\
2019\end{array}$ & $\begin{array}{c}11: 00 \text { to } \\
14: 01\end{array}$ \\
\hline $\begin{array}{l}\text { Black } \\
\text { Beans }\end{array}$ & 3 hours & $\begin{array}{c}\text { Sep, } 11 \\
2019\end{array}$ & $\begin{array}{c}11: 00 \text { to } \\
14: 01\end{array}$ \\
\hline Goat Feets & 5 hours and $45 \mathrm{~min}$ & $\begin{array}{c}\text { Sep, } 21 \\
2019 \\
\end{array}$ & $\begin{array}{c}10: 30 \text { to } \\
16: 15\end{array}$ \\
\hline Nihari & Cooked at night time & $\begin{array}{c}\text { Sep, } 27 \\
2019\end{array}$ & $\begin{array}{c}17: 00 \text { to } \\
8: 30\end{array}$ \\
\hline
\end{tabular}

\section{CONCUSLION}

A solar geyser has been converted into a solar cooker that can be either used for cooking during day and night time and also the stored water inside the storage tank of the system can also be used for cleaning dishes, washing even for bathing. The maximum temperature attained inside the TSU was recorded $98.5^{\circ} \mathrm{C}$ while the minimum temperature attained by the system was recorded $74.3{ }^{\circ} \mathrm{C}$. Using of evacuated tubes collectos the performance parameters of the solar geyser converted solar cooker evaluated under tracking free conditions are statisfactory.

\section{REFERENCES}

[1] R. Muthusivagami, R. Velraj, and R. Sethumadhavan, "Solar cookers with and without thermal storage-a review," Renewable and sustainable energy reviews, vol. 14, pp. 691-701, 2010.

[2] P.-o. b. e. s. H. Deutsche Gesellschaft für Internationale Zusammenarbeit (GIZ) GmbH, Dag-Hammarskjöld-Weg 1-5, "Cooking Energy Compendium," Energypedia, November 1, 20182018.

[3] A. Kundapur, "Review of solar cooker designs," TIDE, vol. 8, pp. 1-37, 1998.

[4] M. M. Mwaura, "Performance of a Double Reflector Solar Box Cooker with Phase Change Material Energy Storage," 2014.

[5] S. Z. Farooqui, "A gravity based tracking system for box type solar cookers," Solar Energy, vol. 92, pp. 62-68, 2013. 
MUHAMMAD BABAR IQBAL received B.Sc. degree in Electrical Engineering (Power) from the City University of Science and Information Technology, Peshawar, Pakistan in 2017. He is currently persuing his Master degree in Renewable Energy Engineering from U.S-Pakistan Center for Advanced Studies in Energy, University of Engineering and Technology, Peshawar, Pakistan.

His research interests includes DC smart grids, power electronics, Wind turbines, renewable energy materials and technology modeling, photovoltaic devices. 